\title{
Vertical Electric Sounding of Leachate Contaminant Plumes at a Dumpsite in Obigbo, Rivers State, Nigeria
}

\author{
TAMUNO, W; *INICHINBIA, S \\ Department of Physics, University of Port Harcourt, Port Harcourt, Nigeria \\ *Corresponding AuthorEmail: sonny.inichinbia@yahoo.com; sonny-inichinbia@uniport.edu.ng
}

\begin{abstract}
The quality of underground water at a dumpsite in Obigbo, Rivers State, Nigeria, was investigated by collecting 7 vertical electrical soundings (VES) using Wenner electrode configuration with current electrode spacing $(\mathrm{AB} / 2)$ ranging from $1.0 \mathrm{~m}$ to $300 \mathrm{~m}$. Field data were acquired using the SAS $300 \mathrm{C}$ resistivity meter and accessories, coordinates and elevation were measured using the Global Positioning System (GPS) at each sounding station. The VES data showed that the area is composed of clay, sandy clay and sand. The contaminated zones have low resistivity and corresponding high conductivity. Two zones were identified, zones of low resistivity and high resistivity with values of $11.3 \Omega \mathrm{m}$ to $21.4 \Omega \mathrm{m}$, and $357.0 \Omega \mathrm{m}$ to $795.0 \Omega \mathrm{m}$ respectively. There is thus, both lateral and downward movement of the contaminant leachate plumes. The results also revealed that the surrounding soil and groundwater around the landfill has not been contaminated to depths exceeding $15.6 \mathrm{~m}$, which is shallower than the productive aquifer depth greater than 37.0 $\mathrm{m}$. Judging from the age of the dumpsite, this site has a good protecting capacity, probably as a result of the presence of sufficient confined layers of clay that have impeded or slowed down the percolation of leachate into the aquifer. The aquifer is the underlying rocks of sand and gravel that are porous which constitute the water body.
\end{abstract}

DOI: https://dx.doi.org/10.4314/jasem.v23i12.24

Copyright: Copyright $@ 2019$ Tamuno and Inichinbia. This is an open access article distributed under the Creative Commons Attribution License (CCL), which permits unrestricted use, distribution, and reproduction in any medium, provided the original work is properly cited.

Dates: Received: 30 November 2019; Revised: 20 December 2019; Accepted: 23 December 2019

Keywords: Dumpsite, Resistivity, Sounding, Leachate, Aquifer.

Waste is generated universally and is a direct consequence of all human activities. Human activities on earth give rise to residual materials which are not of immediate use where they arise. These residual materials may be recycled, reclaimed, or reused; otherwise they constitute waste which will ultimately be released to the environment in mobile form or insitu. In Nigeria, Adebibu (1985) grouped solid wastes into eight classes, namely domestic, municipal, industrial, agricultural, pesticides, residential and hazardous wastes. However, solid waste can also be classified as biodegradable, or non-biodegradable, soluble or insoluble, organic or inorganic, toxic or non-toxic (Kostawa, 2006; Ajadike, 2007). Irrespective of the classification of solid wastes, most of the urban wastes are degradable which aids leachate formation and migration compared to nonbiodegradable that can last for many years without any sign of decomposition. The biosphere has the capacity to transform many wastes over time, either into harmless products or into nutrients which can be used again. Hazardous wastes include household items, sewage, sludge, waste from manufacturing industries etc. Waste placed in landfills or open dumpsites are subjected to either underflow or infiltration from precipitation. Areas near landfills have great possibility of groundwater contamination because of potential pollution source of leachate. Naturally depth from surface, soil type, bed rock, geology, permeability of sediments and climatic variation affect groundwater quality. The disposal of solid waste into the ground has been recognized as the major source of groundwater contamination as described by Christopher and Jones (1999); Udom et al. (1999); Ibe and Njoku (1999); Olayinka and Olayiwola (2000); Roseqvist et al. (2003); Udom and Esu (2004); Ehirim et al., (2009a); and Ehirim et al. (2009b). Contrary to the widely held theoretical view of groundwater being the "safest" water for consumption, some wells are found to be polluted in terms of temperature, mineral contents, particle solute, organic matter and bacterial concentration. These contaminations are mainly got from municipal land fill leachates which are highly concentrated complex effluents that contain dissolved organic matters; inorganic compounds such as ammonium, calcium, magnesium sodium, potassium, iron, sulphates, chlorides, copper, lead, nickel, zinc and xenobiotic organic substances. The objective of this work is to apply the vertical electric soundings to measure the leachate contaminant plumes at a dumpsite at Obigbo, Rivers State, Nigeria.

\section{MATERIALS AND METHODS}

This work employed modern equipment such as terrameter SAS 300C, stainless steel electrodes, reels 
of cables, hammer, GPS, RES2DINV and the state-ofthe-art techniques that match best practices in other parts of the world.

The Study Area: The study area (Oyigbo Town) is located along Port Harcourt-Aba expressway in Rivers State. The site is located between latitudes $4^{0} 53^{1} \mathrm{~N}$ and $4^{0} 54^{1} \mathrm{~N}$ and longitudes $7^{0} 01^{1} \mathrm{E}$ and $7^{0} 21^{1} \mathrm{E}$. This area depicts flat topography with a mean elevation of $28 \mathrm{~m}$ above mean sea level. It is also characterized by alternate wet and dry seasons with a total annual rainfall of about $240 \mathrm{~cm}$; relative humidity of over $90 \%$ and mean annual temperature of $27^{\circ} \mathrm{C}$.

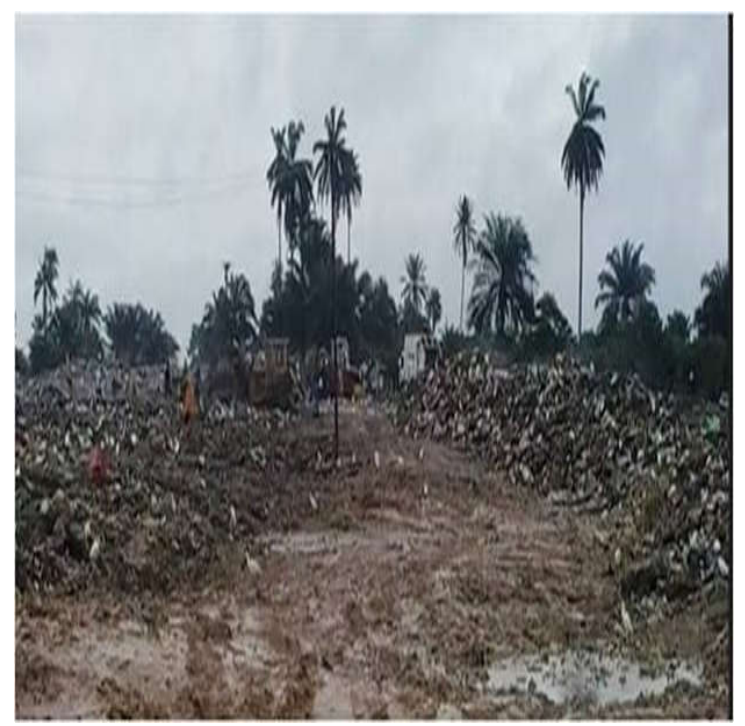

Fig 1. The open dumpsite where the investigation was carried out showing different kinds of wastes dumped in the study area.

Geological Settings: The geology of the site revealed top soil composed of silt, clay, laterite, fine to coarse grain sands and gravel. The area under study is a typical Niger Delta environment of which the sedimentary basin has been subdivided into three stratigraphic units, namely, the Benin, Agbada and Akata Formations in order of increasing age (Short and Stauble, 1967). Figure 1 is the geological map of the study area.

Methodology: Geophysical methods are used to obtain accurate information about subsurface condition, such as type and depth of rock materials, depth to groundwater systems and bedrock. For the purpose of this survey, the DC resistivity method was employed. Principal equipment used include ABEM Terrameter (SAS 300C), Global positioning system (GPS), measuring tape, cable reels, stainless steel electrodes, battery, hammers, cutlass, and pegs. Two (2) profiles, each $100 \mathrm{~m}$ long were used for the 2D resistivity survey in the study area. Both Wenner and
Schlumberger electrode configurations were employed. Check Inichinbia and Sule (2018a\&b) and Agbemuko, et al. (2017) for a description of the mathematical detail and analysis of data.

Data Analysis and Interpretation: Groundwater may not be contaminated at the inception of waste deposition in the landfill. The age of the landfill significantly affects the quality of leachate formed. The ageing of a landfill is accompanied by increased quantity of leachate. 2D resistivity tomography was employed in the study area to confirm the presence and extent of leachate contaminant plume in the soil and groundwater due to the landfill in the area. The RES2DINV software displayed the results of the 2D imaging field data after processing as inverse pseudosection that gives the true resistivities of the subsurface layers as a function of vertical depth.

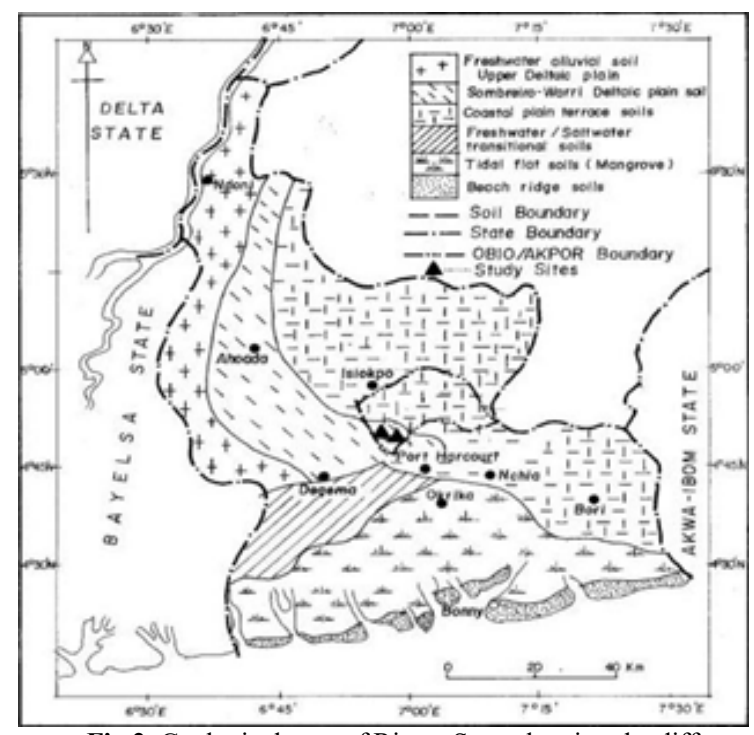

Fig 2. Geological map of Rivers State showing the differen sedimentary rocks in the study area. Sonbreiro-Warri Deltaic plain soils and Coastal plain terrace soils dominate this area.

Figure 3 shows the result of the inverse model resistivity section of the first profile (profile 1) which was laid about $15 \mathrm{~m}$ away from the edge of the landfill site. The zones identified from the inverse model resistivity section are zones of low resistivity, zones of intermediate resistivity and zones of high resistivity. The inverse model resistivity section has resistivity values between $<21.4 \Omega \mathrm{m}$ to greater than $357.0 \Omega \mathrm{m}$. The low resistivity zones (deep blue), with resistivity values $<21.4 \Omega \mathrm{m}$ to $>71.5 \Omega \mathrm{m}$ is located throughout the entire profile length, and at depths of $0.625 \mathrm{~m}$ to over $7.21 \mathrm{~m}$. this zone is interpreted as zone of leachate contamination from the top soil. Migration to the shallow aquifer is obvious between $6.72 \mathrm{~m}$ and a little above $10.0 \mathrm{~m}$, due to the presence of unconsolidated and porous materials, probably sands and gravels in 
the subsurface. This zone is underlain by more resistive layers ranging from $>80.0 \Omega \mathrm{m}$ to $160.0 \Omega \mathrm{m}$ (light green to yellow). The high resistivity zone (yellow to purple) increases from $160.0 \Omega \mathrm{m}$ to over $357.0 \Omega \mathrm{m}$ at three different shallow surface points. The highest resistive zone (purple) was isolated between depths of $12.1 \mathrm{~m}$ to $15.6 \mathrm{~m}$ at $40.0 \mathrm{~m}$ to 70.0 $\mathrm{m}$ surface points along the profile length. It is probably a zone of increasing resistivity which was intepreted as porous permeable layer of varying grain sizes, thickness and moisture content.

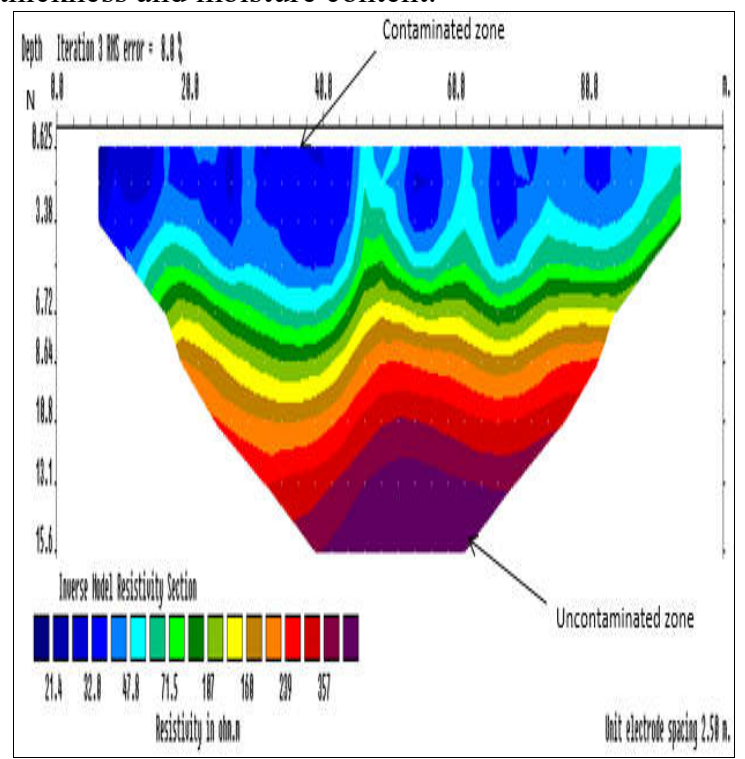

Fig 3. Inverse model resistivity section of profile 1 showing resistivity contrasts laterally withy depth.

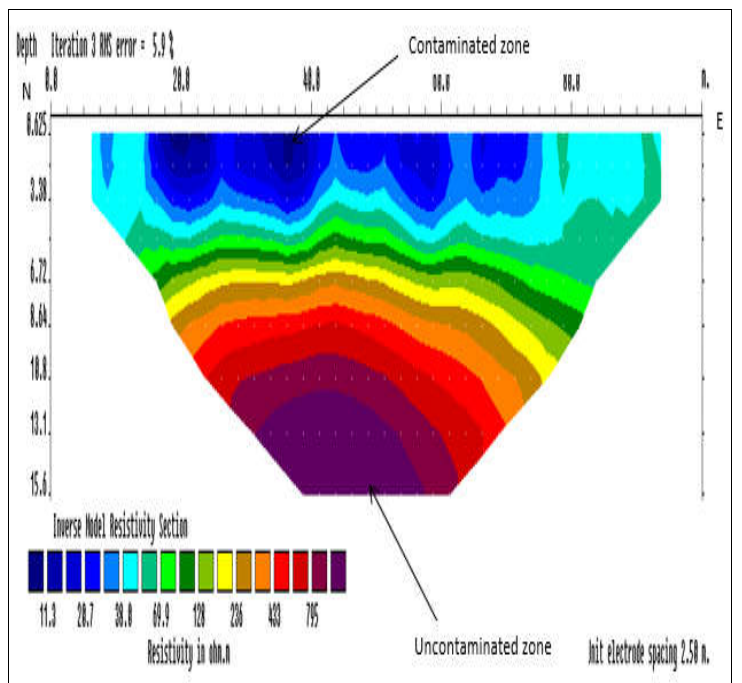

Fig 4. Inverse model resistivity section of profile 2 showing resistivity contrasts laterally withy depth

Figure 4 is the inverse model resistivity section of the second profile (profile 2), of this survey, with RMS error $5.9 \%$ and three main resistivity zones were clearly isolated. The very high resistivity zone, 795.0
$\Omega \mathrm{m}$ to $236.0 \Omega \mathrm{m}$ (orange to purple) spanning throughout the middle section is an indication of leachate. The high resistivity zone is located at the based area at depth of $11.5 \mathrm{~m}$ to $15.6 \mathrm{~m}$ and surface point $30.32 \mathrm{~m}$ to $58.5 \mathrm{~m}$. There are prominent zones of anomalously low resistivity $<11.3 \Omega \mathrm{m}$ to $>70.0 \Omega \mathrm{m}$ (deep blue) isolated at the upper part of the section, at depths ranging from $0.625 \mathrm{~m}$ to over $6.72 \mathrm{~m}$ and at surface points along the entire profile length. This is interpreted as leachate contaminant containing dissolved organic and inorganic materials which have migrated down the subsurface to the shallow aquifer. This result shows both downward and lateral movement of the leachate plumes as this dumpsite has poor protective capacity.

\section{RESULTS AND DISCUSSION}

The results of the inverse model sections reveal that the surrounding soil and groundwater around the landfill has not been contaminated to depths exceeding $15.6 \mathrm{~m}$ which is below the productive aquifer depth $>37 \mathrm{~m}$ in the area. The $2 \mathrm{D}$ resistivity imaging mapped three distinctive zones of anomalously low and high resistivity. There is a zone of increasing resistivity (yellow to green). The anomalously low resistivity (deep blue) in the profiles were interpreted as highly conductive leachate contaminant plumes (as a result of decomposing landfill wastes) containing organic and inorganic subtances, dangarous pathogens, and dissolved solids, which varies in resistivity ranging from $<21.4 \Omega \mathrm{m}$ to $357.0 \Omega \mathrm{m}$ and the leachate contaminant plume is observed to have seeped from surface points to depths exceeding $7.72 \mathrm{~m}$ in the inverse model sections. This observed seepage is enchanced by the nature of the permeable sandy layer overlying the acquifer. The zones of increasing resistivity (green to yellow) with resistivity ranging from $71.9 \Omega \mathrm{m}$ to $107 \Omega \mathrm{m}$ and $69.9 \Omega \mathrm{m}$ to $128.0 \Omega \mathrm{m}$ in the entire profile were also identified as porous and permeable sandy layers of varying grain sizes and moisture content. The zones of anomalously high resistivity (pink to purple) with resistivity greater than $357.0 \Omega \mathrm{m}$ and $795.0 \Omega \mathrm{m}$ in the entire profile and this was interpreted as water.

There is therefore a possibility of leachate generation plume extension and migration at the base of the urban landfill owing to the decomposition of solid wastes and frequent surface water ingression from precipitation. There are zones of anomalously low resistivity across the profiles length, interpreted as highly conductive leachate contaminants containing dangerous pathogens, and dissolved wastes and zones of anomalously high resistivity probably sand saturated with water. However, concentration $(\mathrm{mg} / \mathrm{L})$ of leachate constituent could be grouped in phases 
namely; transition (0-5 years), acid formation (10-20 years) and finally maturity ( $>20$ years).

Also, there is a zone of increasing resistivity which was intepreted as porous permeable layer of varying grain sizes, thickness and moisture content. The hydrogeological features of the study area indicated that contaminants derived from the waste disposal sites infiltrated through the vulnerable sandy aquifer and hence to the groundwater. The study has successfully demostrated that 2D resistivity imaging can be employed to investigate pollutant effects of lanfill on the surface materials and groundwater and the probable limits of the leachate plumes from solid wastes.

Water quality management is an issue that must be given top priority. The hydrogeological features of the vulnerable sandy aquifer makes this site not suitable for waste disposal. This is becauce it may cause contaminants to infiltrate through the groundwater. Continuous operation of waste disposal facilities in an area without environmental impact assessment and precautions may lead to serious health problems. Therefore planning of landfill site must involve the state-of-the-art solutions to landfill problems such as appropriate disposal of wastes by bagging, and waterproofing (lining) the base of the landfill to prevent infiltration of the effluent. Public awareness campaign should be launched by the relevent agencies of government informing the populace on the health hazards of indiscriminate dumping of wastes and the danger of drilling borehole near landfill without proper geological/geophysical imaging of the site.

Conclusion: The results of the 2D resistivity imaging show the presence of leachate contaminant in soil and groundwater in the dumpsite and at depths exceeding $15.6 \mathrm{~m}$ which is within the aquifer system of the area. The leachate has contaminated the subsurface and groundwater within the vicinity of the dumpsite and constitutes a hazard to the local aquifer, so indiscriminate dumping of solid wastes should not be encouraged. The $2 \mathrm{D}$ resistivity imaging isolated two zones in each of the profiles mapped around the dumpsite.

Acknowledgement: The authors are thankful to $\mathrm{Mr}$. I.P.C. Okorie for his invaluable assistance and all others whose names are not listed here but contributed to the success of this work.

\section{REFERENCES}

Adebibu, EA (1985). Quality Assessment of Groundwater in the vicinity of dumpsites in Lagos, Nigeria. J. of appl. Sci. 2(1): 39-44
Agbemuko, OS; Tamunobereton-Ari, I; Ngah, SA (2017). Determination of the effects of dumpsites on aquifer at Port Harcourt metropolis, Rivers State, Nigeria. IOSR-J. of Appl. Phys, 9(6): ver. I, $41-54$.

Ajadike, A.T (2007). Waste Management towards Sustainable Development in Nigeria. A Case Study of Lagos State, Nigeria. Int.NGO J. 4(4): 173-179.

Christopher, LB; Jones, SA (1999). Subsurface Evaluation of the West Parking Lot and Land filling 3 Areas of Air force Plant 4, Fort Worth, Texas, Using 2-D Direct Current Resistivity Profiling. US Geol. Survey. 1-11.

Ehirim, CN; Ebeniro, JO; Ogwu, DA (2009a). A geophysical and Hydro-physiochemical impact of a solid Waste Landfill in Port Harcourt municipality, Nigeria. Pac, J. of Sci.and Technol. 10: $596-603$.

Ehirim, CN; Ebeniro, JO; Olanegan, OP (2009b). A geophysical investigation of soild waste landfill, using 2-D Port Harcourt municipality, Rivers state, Nigeria. Pac. J. of Sci. and Technol. 10: 604 $-613$.

Ibe, KM; Njoku, JC (1999). Migration of contaminants in groundwater at a landfill site in Owerri, South East, Nigeria. J. of Environ. Hydrol. 7(8): 1 - 9.

Inichinbia, S; Sule, PO (2018a). Evaluation of the layering of rock strata and basement rock depth of a university teaching hospital premises in northern Nigeria. J. of Appl. Sci. and Environ. Manage. 22 (4): $597-603$.

Inichinbia, S; Sule, PO (2018b). 2D geo-electrical imaging for groundwater exploration in Shika, along Zaria-Funtua road north of Ahmadu Bello University main campus, Samaru, Zaria. $J$. of Appl. Sci. and Environ. Manage. 22 (4): $609-$ 612.

Olayinka, AI; Olayiwola, MA (2000). Integrated use of Geophysical imaging and hydro-chemical Methods in delineating limit of polluted surface and groundwater at a landfill site in Ibadan Area, S.W, Nigeria. J. of Mining and Geol. 37(1): 193 198. 
Rosqvist, H; Dahlin, T; Fourie, A; Rohrs, L; Bengtseeon, A; Larsson, M (2003). Mapping of Leachate plumes at two landfill sites in South Africa Geoelectrical Imaging Techniques. Proceedings of $9^{\text {th }}$ Int. Waste Manage. and Landfill Symp. Cagliari, Italy. 1 - 10.

Short, RC; Stauble, AJ (1967). Outline of Geology in the Niger Delta, $A A P G, 51(5): 761$-779.
Udom, GJ; Esu, EO (2004). A preliminary Assessment of the Impact of Solid Wastes on Soil and Groundwater System in Parts of Port Harcourt city and its environs, Rivers State, Nigeria. Global J. of Environ. Sci. 4(1): 234 - 239

Udom, GJ; Etu - Efetor, JO; Esu, EO (1999). Hydrogeochemical of Groundwater in part of Port Harcourt and Tai Eleme Local Government Area, Rivers State. Global J. of Pure and Appl. Sci. 5: $545-551$ 